\title{
A behavioural intervention reduced depression and organic symptoms in elderly people in residential homes
}

\author{
Proctor R, Burns A, Stratton Powell H, et al. Behavioural management in nursing and residential homes: a randomised \\ controlled trial. Lancet 1999 Jul 3;354:26-9.
}

QUESTION: In elderly people living in residential and nursing homes, can a behavioural intervention by an outreach team improve depression, behavioural problems, and physical function?

\section{Design}

Randomised (allocation concealed*), blinded (patients),* controlled trial with 6 months of follow up.

\section{Setting}

10 residential homes and 2 nursing homes in south Manchester, UK.

\section{Patients}

120 elderly people (mean age 82 y, 82\% women) living in residential or nursing homes and whom staff identified as being difficult to manage. $88 \%$ completed the study.

\section{Intervention}

Homes were matched according to size and accreditation status. 1 home in each pair was randomised to receive the intervention and the other to a control group. 6 homes with 60 participants were in each group. In the intervention group, staff attended seven 1 hour seminars on topics related to behavioural problems in dementia to improve their knowledge and skills. A psychiatric nurse also visited the homes every week to provide advice and support and to help staff to develop and achieve goals for managing behavioural problems.

\section{Main outcome measures}

Organic and depressive symptoms (automatic geriatric examination for computer assisted taxonomy [AGECAT], score range 1 and $2=$ subclinical to $5=$ most severe), behavioural problems (Crichton Royal behavioural rating scale, score range $0=$ no problems to

Behavioural intervention by a geriatric psychiatry team $v$ no intervention for elderly people in residential or nursing homes $\dagger$

\begin{tabular}{|c|c|c|c|}
\hline \multirow[b]{2}{*}{$\begin{array}{l}\text { Outcomes at } 6 \\
\text { months }\end{array}$} & \multicolumn{2}{|c|}{ Mean score $(95 \% \mathrm{CI})$} & \multirow{2}{*}{$\begin{array}{l}\text { Adjusted } \\
\text { mean score } \\
\text { difference } \\
(\mathrm{Cl}) \dagger\end{array}$} \\
\hline & Intervention & Control & \\
\hline $\begin{array}{l}\text { Organic } \\
\text { symptoms } \\
\text { (AGECAT) }\end{array}$ & $\begin{array}{l}2.4 \\
(1.5 \text { to } 3.2)\end{array}$ & $\begin{array}{l}3.0 \\
(2.6 \text { to } 3.5)\end{array}$ & $\begin{array}{l}-0.7 \\
(-1.1 \text { to }-0.2)\end{array}$ \\
\hline $\begin{array}{l}\text { Depressive } \\
\text { symptoms } \\
\text { (AGECAT) }\end{array}$ & $\begin{array}{l}0.5 \\
(0.3 \text { to } 0.8)\end{array}$ & $\begin{array}{l}0.9 \\
(0.6 \text { to } 1.3)\end{array}$ & $\begin{array}{l}-0.5 \\
(-0.8 \text { to }-0.1)\end{array}$ \\
\hline $\begin{array}{l}\text { Behaviour } \\
\text { (Crichton } \\
\text { Index) }\end{array}$ & $\begin{array}{l}13.2 \\
(7.6 \text { to } 18.8)\end{array}$ & $\begin{array}{l}15.3 \\
(12.6 \text { to } 18.1)\end{array}$ & $\begin{array}{l}-0.7 \\
(-3.0 \text { to } 1.6) \ddagger\end{array}$ \\
\hline $\begin{array}{c}\text { Physical disability } \\
\text { (Barthel index) }\end{array}$ & $\begin{array}{l}13.2 \\
(9.5 \text { to } 16.9)\end{array}$ & $\begin{array}{l}11.0 \\
(9.0 \text { to } 13.0)\end{array}$ & $\begin{array}{l}0.9 \\
(-0.8 \text { to } 2.7) \ddagger\end{array}$ \\
\hline
\end{tabular}

AGECAT=automatic geriatric examination for computer assisted taxonomy. †Mean differences favour the intervention group and are adjusted for sex, age, and baseline scores. ‡Not significant.
$38=$ severe problems), and physical disability (Barthel activity of daily living index, score range $0=$ dependent to $20=$ independent but not necessarily normal).

\section{Main results}

After adjustment for baseline variables, the behavioural intervention by the outreach team led to improvement in organic $(\mathrm{p}=0.002)$ and depressive $(\mathrm{p}=0.004)$ symptoms but not to changes in behavioural problems or physical disability compared with no intervention (table).

\section{Conclusion}

In elderly people living in residential or nursing homes, a behavioural intervention by an outreach team improved depressive and organic symptoms but not behavioural problems or physical disability.

*See glossary.
Source of funding. National Health Service Executive.

For correspondence: Professor A Burns, University of

Manchester, School of Psychiatry and

Behavioural Sciences,

Withington Hospital,

Manchester M20 8LR,

UK. Fax +44 (0) 161

2914364.

Abstract also appears in Evidence-Based

Nursing.

\section{COMMENTARY}

As the number of nursing home patients increases worldwide and life expectancy continues to climb, behavioural problems related to mood and dementia will take up more clinical time. Proctor $e t$ al have developed a behavioural intervention which was studied in a randomised controlled trial. This behavioural intervention measured a training programme for nursing home staff, which aimed to address specific disruptive behaviours. The patients' depression and cognitive function were measured before and at the completion of the intervention. The training programme consisted of seven 1 hour lectures on psychosocial issues and 6 months of weekly consultations with a psychiatric nurse. The intervention group showed marked improvement in depression and cognitive function as a result of this educational psychosocial intervention.

This study complements previous research supporting psychosocial interventions as effective treatments for addressing depressive symptomatology in this population. One study showed that frequent recreational activities can improve depressive symptoms. Another investigation found that both cognitive behavioural and visual imagery groups improved mood and memory. ${ }^{2}$ Alternatively, in some nursing home patients, psychosocial interventions may be more effective than medications. One recent medication study found little benefit for antidepressant medication in nursing home patients who have minor depression.

Proctor et al have provided an easily replicable psychosocial intervention to address the behavioural problems associated with depressive symptoms and cognitive impairment in nursing home patients.

Irene Ortiz, MSW, MD

University of Mexico

Albuquerque, New Mexico, USA

1 Rosen J, Rogers JC, Marin RS, et al. Control-relevant intervention in the treatment of minor and major depression in a long-term care facility. Am J Geriatr Psychiatry 1997;5:247-57.

2 Abraham IL, Neundorfer MM, Currie LJ. Effects of group interventions on cognition and depression in nursing home residents. Nurs Res 1992;41:196-202.

3 Salzman C. Practical considerations for the treatment of depression in elderly and very elderly long-term care patients. J Clin Psychiatry 1999;60(suppl 20):30-3. 